\title{
Anna Sucheni-Grabowska, Wolność i prawo w staropolskiej koncepcji państwa, Muzeum Historii Polski, Warszawa 2009, 272 strony.
}

Prezentowana książka stanowi zbiór dziewięciu tekstów znakomitego i cenionego historyka ustroju, prawa i praktyki politycznej Rzeczypospolitej szlacheckiej prof. Anny Sucheni-Grabowskiej. Znalazły się w niej artykuły już wcześniej opublikowane w czasopismach, pracach zbiorowych lub księgach pamiątkowych (często niskonakładowych, trudno dostępnych), a także tekst dotąd nieznany, napisany przez autorkę w 1990 r. specjalnie do przygotowywanej wówczas księgi o prymasach polskich, która się ostatecznie nie ukazała. Wydany przez Muzeum Historii Polski w Warszawie tom poświęcony został kluczowym zagadnieniom funkcjonowania Rzeczypospolitej, zwłaszcza w XVI w., ukazując tym samym obszary dotychczasowych zainteresowań badawczych prof. SucheniGrabowskiej. Zebranie w jednej pozycji prac powstałych w latach 1963-2001 pozwala poznać część ogromnego dorobku tej autorki.

W słowie od wydawcy czytamy, iż zbiór artykułów otwiera niepublikowany tekst poświęcony osobie Jana Łaskiego, natomiast pozostałe prace są uporządkowane chronologicznie, wedle momentu publikacji. Spis treści i zawartość książki przeczą jednak tym słowom. Pierwszy tekst nosi bowiem taki sam tytuł, jakim został opatrzony cały zbiór, a więc Wolność i prawo w staropolskiej koncepcji państwa (2001), a przy ułożeniu kolejnych opracowań nie przyjęto chronologii. Nie ma to jednak większego znaczenia, gdyż autorytet - jak sądzę - i styl pisarski autorki niwelują wszelkie niedociągnięcia wydawnicze oraz gwarantują przyjemną lekturę.

Większość wybranych do ponownej publikacji tekstów dotyczy zagadnień instytucjonalnych I Rzeczypospolitej, zwłaszcza staropolskiego parlamentaryzmu. W tej kwestii autorka wypowiedziała się w otwierającym omawianą pozycję artykule. Pisząc o pryncypialnych elementach staropolskiej koncepcji ustrojowej - wolności i prawie - zaprezentowała, jak te desygnaty państwa polskiego odnajdywały swoje praktyczne przełożenie $\mathrm{w}$ instytucjach parlamentarnych. Zapoznając czytelnika z zagadnieniami prawnowolnościowej koncepcji staropolskiego państwa, zarysowała także rozbieżne oceny o naszym dziedzictwie historycznym (od doktryny „Stańczyków” i „czarnej legendy” do historyków zapisujących karty „złotej legendy”), wskazując jednocześnie, że współczesny czytelnik poszukuje wyważonych ocen i dowodów nie do zakwestionowania. W artykule Polskie tradycje demokratyczne epoki odrodzenia (1983) prof. Sucheni-Grabowska ukazała podstawowe i najbardziej znamienne cechy staropolskich urządzeń ustrojowych na tle państwa renesansowego, przytaczając jako przykład Francję i Anglię, a także projekty reform inicjowanych przez obóz demokracji szlacheckiej, identyfikowany z ruchem "egzekucji praw".

W innym z tekstów (Rola mandatu poselskiego w dawnej Polsce na tle porównawczym, 1999) znajdziemy z kolei rozważania autorki nad zagadnieniem wciąż jeszcze 
przez badaczy systemu parlamentarnego dawnej Polski niewyczerpanym, a mianowicie nad rolą pełnomocnictwa poselskiego, które to zagadnienie wpisała w szerszy problem - rolę mandatu poselskiego na zgromadzeniach stanowych zachodnio- i środkowoeuropejskich.

Kolejne opracowanie (Walka o wymiar i przeznaczenie kwarty w końcu XVI i na początku XVII wieku, 1963), które mieści się w kręgu rozważań instytucjonalnych, poświęcone zostało walce o sposób wymierzania i przeznaczenia kwarty. Sprawa ta w ocenie prof. Sucheni-Grabowskiej stanowiła tylko ,jeden z odcinków złożonej linii, wzdłuż której ścierały się dążenia do zdobycia politycznej przewagi w państwie między panującym ogółem szlacheckim oraz magnaterią, skupiającą w swym elitarnym rodowym kręgu urzędy ministerialne, godności senatorskie i tenuty dóbr królewskich".

Ostatni z tekstów (Królowe a następstwo tronu: Zofia, Bona i Ludwika Maria, 1992), który niejako zamyka rozważania nad stroną instytucjonalną dawnej Polski, traktuje z kolei o zagadnieniu następstwa tronu, a przede wszystkim stosunku monarchiń do tej kwestii. Ukazane przez autorkę poczynania królowych, podejmowane na rzecz zagwarantowania tronu swym najbliższym, „wykazywały z reguły nieznajomość ducha praw Rzeczypospolitej”, któremu obca była instytucja elekcji vivente rege.

Kolejne publikowane artykuły uzupełniające się i poszerzające niejako wiedzę o funkcjonowaniu staropolskiego państwa o ludzki jego wymiar poświęcone zostały rozważaniom na temat elity władzy Rzeczypospolitej „Złotego Wieku”. Prof. SucheniGrabowska stwierdziła wręcz, że badania nad instytucjami, jeśli nie zostaną poprzedzone poznaniem przemian w systemie rządzenia i mechanizmów sprawczych tych przemian, będą stanowiły „daremny czasami trud wznoszenia formalistycznych konstrukcji na nieznanych i żywych treściach procesu dziejowego”. Stąd wiele miejsca poświęciła w swoich badaniach przeanalizowaniu pozycji i praktycznej funkcji monarszej elity władzy, a ich efektem są m.in. teksty: Badania nad elita władzy w latach 1551-1562 (1976), Obsadzanie urzędów senatorskich $i$ ministerialnych przez Zygmunta Augusta (1987). W pierwszym tekście autorka wykazała, iż w dwunastoletnim okresie panowania Zygmunta Augusta (1551-1562) monarsza elita władzy została sprowadzona do roli posłusznego asystenta, a król jeszcze bardziej skupił władzę w swoich rękach, w drugim zaś ukazała, jak tego dokonał. Zygmunt August, zmierzając konsekwentnie do niezależności przy formowaniu ekipy dostojniczej, starał się powoływać ludzi dobranych według własnego uznania, przełamując tradycję obsadzania urzędów senatorskich przedstawicielami miejscowych rodów, nominując wielokrotnie wbrew zasadzie przestrzegania kolejności krzeseł senatorskich, czy też odchodząc od praktyki obsadzania ważniejszych wakansów dostojniczych na sejmach, gdzie wywierano na niego różne naciski polityczne.

Potwierdzenie tez postawionych w opracowaniach dotyczących elity władzy znajdziemy również w dwóch następnych artykułach omawianego zbioru. Ukazują one sylwetki Jana Łaskiego (Jan Łaski, kanclerz, prymas i mąż stanu (1456-1531), 2009) i Jana Ocieskiego (Nieproste drogi kariery Jana Ocieskiego, 2000). Miłośnicy biografistyki, choć nie tylko oni, mają okazję poznać zawiłe drogi karier tych wybitnych działaczy publicz- 
nych. Szczególnie interesujący jest tekst poświęcony osobie prymasa. Do tej pory bowiem, ten, w ocenie Andrzeja Frycza Modrzewskiego, clarissimus et sapientissimus vir, religionis et Reipublicae nostrae princeps, nie doczekał się szerszej, naukowej biografii. Dlatego też szkic pióra prof. Sucheni-Grabowskiej, choć nieuwzględniający najnowszej literatury przedmiotu, stanowi krok naprzód w poznaniu sylwetki osoby, która na to niewątpliwie zasługuje.

Podjętą inicjatywę wydawniczą, której celem było powtórne zainteresowanie czytelników problematyką podejmowaną przez prof. Sucheni-Grabowską i uchronienie jej tekstów przed zapomnieniem, a ponadto ułatwienie do nich dostępu historykom, studentom, należy uznać za słuszną i cenną. I choć nie jest to odosobniona inicjatywa - w 2009 r. zbiór swoich artykułów opublikował m.in. prof. Stanisław Salmonowicz ${ }^{1}$ z pożytkiem dla nauki byłoby podejmowanie podobnych kroków w przyszłości i przez innych wybitnych historyków.

Diana Maksimiuk

${ }^{1}$ Kilka minionych wieków. Szkice i studia z historii ustroju Polski, Universitas, Kraków 2009, stron188. Na temat książki zob. „Palestra” 2009, nr 9-10, s. 217-218. 